\title{
The Roots and Routes of "Imperium in Imperio": St. Clair Drake, The Formative Years
}

\author{
Andrew J. Rosa
}

Chicago: like the back of your hand;
the earlier railroad the same.
Just as heavily veined and stressed,
you know and carry with you whole
all of our suffering; a spread of pain
which, we know, you conceal quietly.
Andrew Salkey, 1973. ${ }^{1}$

My earliest memories of a black college involve an episode fifty-six years ago . . . My father had taken me . . . with him on a visit to his alma mater, the school that had fashioned him into a preacher and my mother into a schoolteacher, Virginia Theological Seminary and College ... He had come there as a young immigrant from Barbados; my mother had come across the mountains from Staunton in the Shenandoah Valley. I remember that visit . . . Years later I watched black Baptists giving suppers and begging "to keep the Seminary alive" ... The Seminary was theirs. It is still alive, impecunious and struggling. They refuse to let it die. St Clair Drake, $1971 .^{2}$ 


\section{Introduction}

In 1899, Sutton Griggs published Imperium in Imperio, an obscure work of utopian fiction that unfolds around the creation of a separate black empire within the United States. One of the two main protagonists of the novel, Belton Piedmont, is a patriotic American, who believes that black people must make an attempt to persuade whites to grant them justice before wholly surrendering to a separate racial destiny. Failing in this mission, Piedmont reasoned, whites would be responsible for having created an empire within an empire. In contrast to Piedmont, Griggs introduced the wrathful Bernard Belgrade as a figure driven by his all-consuming hatred of whites to make a separate black empire a reality. Ending his novel with Piedmont's execution by Belmont as a traitor of the Imperium, Griggs offers the ascendency of a black nationality over a hopeful vision of an integrated America. The duality of aims pursued by Piedmont and Belmont, which ultimately resulted in the creation of an independent black state, underscored for Griggs the tension around what it meant to be a "Negro" and an "American" at the precise moment when a system of segregation, motivated by the eugenicist impulse of upholding racial purity, was clarifying the spatial boundaries between whites and blacks across the South. ${ }^{3}$

Almost a half-century later a variation on this theme of imperium in imperio assumed sociological meaning in St. Clair Drake and Horace Cayton's Black Metropolis. Published by the University of Chicago Press in 1945, Black Metropolis offered a view of an urban black community "in the final stages of the Depression and in the midst of the Second World War." ${ }^{\prime}$ Formed from a longer history of neglect and the inequality of opportunities in Chicago, the Bronzeville of Black Metropolis was the product of a color line and pervasive discrimination, but a world distinctive in its attributes and belonging entirely to black people. Devoid of the sentimentalism and overt political preaching of Griggs' utopian novel, Black Metropolis showed black people as constantly striving to overcome the deprivations and impoverishment of discrimination in housing and employment while "tenaciously clinging to life, liberty, and happiness" through their own organizations and institutions. "This was the world of their relatives and friends. They knew no other!"'5

In its own time this view of an urban black community underscored the attachment black people developed for a way of life seen as essential for survival and getting ahead in a world controlled by whites and called into question the extent to which the modernizing forces of city were, as Robert Park theorized, sweeping away the primitive system of caste most commonly associated with the rural south. ${ }^{6}$ As James B. McKee observed, the real significance of Black Metropolis to urban sociology was found in its rich description of a separate black community. That Bronzeville was able to take root and flourish suggested that the color line in Chicago was less rigid than the system of southern caste, even allowing, in certain areas, for some degree of interracial association. However, as Faye V. Harrison contends, the full extent of black people's separate spatial 
existence in Bronzeville also revealed that neither was it equivalent to the ethnicity of European immigrants. ${ }^{7}$ Against theories of assimilation, which offered a conception of urban ghettos as the problem of behavioral and cultural affinities, Bronzeville was evidence of persistent and widespread racism in American society, reinforcing the boundaries of a black life world: an imperium in imperio, a metropolis within a metropolis, a Bronzeville in the middle of Chicago's South Side.

Though sacrificed on the altar of liberal sociology's conservative assumptions supporting the inevitability of assimilation and, by extension, a linear narrative of American progress, Black Metropolis showed how a discernibly black ghetto, whatever its deficiencies, constituted a community within which a population was forced to construct a framework for an organized way of life. ${ }^{8}$ Moreover, at a moment when sociology seemed unaware of the potential for overt racial conflict, Black Metropolis anticipated the Black Power rebellions of the 1960s by acknowledging the existence of nationalistic, non-assimilative sentiment informed by race pride, on the one hand, and a long-held resentment at white oppression, on the other. In addition to highlighting the failure of a perspective within the sociology of race relations in its own time, Black Metropolis continues to have profound implications for urban sociology and anthropology. Long before Henri Lefebvre and other situationist theorists began to theorize spatiality, it was Drake, along with Cayton, who ethnographically documented the racial construction of space and foreshadowed observations made by scholars like John Jackson, Loïc Wacquant, and Sudhir Vinkatesh, who are now forging new directions in American Studies scholarship by returning to the ghetto to document the struggles of the black urban poor. ${ }^{9}$

The significance of Black Metropolis in these terms specifically speaks to the importance of Drake's place in the history of urban anthropology and sociology. Responsible for writing twenty-two of the twenty-three chapters of Black Metropolis, Drake, more than Cayton, was the main architect of this groundbreaking view of an urban black community, a fact never before publically acknowledged in discussions of this work. ${ }^{10}$ The study's ethnographic perspective, coupled with its emphasis on social organization around caste and class concepts, marks the specific influence of social anthropology on Drake while a graduate student of William Lloyd Warner and Robert Redfield at the University of Chicago in the 1930s. As evidenced by the direct involvement of Cayton and the introduction by the novelist Richard Wright, Black Metropolis also locates Drake within the context of a vibrant Chicago renaissance that linked the University of Chicago to black intellectuals, artists, and activists who moved through the city's South Side during this period. ${ }^{11}$ For these reasons Black Metropolis can also be read as an artifact from a particular era in Drake's life history, revealing of the communities that formed him and the degree to which his profound insights were rooted in and routed through a reworking of anthropology and a black public sphere of political and intellectual consciousness. ${ }^{12}$ 
Along a much longer trajectory, Black Metropolis can also be said to reflect Drake's sustained interest in the study of local black communities nationally and internationally over a period of nearly two decades. In other words, Drake's observation of the black condition did not settle on Black Metropolis, but grew from his previous involvement in a study of white landholders and black tenant farmers in the declining cotton-producing region of Adams County, Mississippi in the early 1930s and continued, after his study of Bronzeville, through his examination of the small Black Diaspora community of Tiger Bay in Cardiff, Wales prior to the wave of West Indian immigration to England in the 1950s and 1960s. ${ }^{13}$ In the Deep South, Drake discovered how the majority of blacks were bound to the hardships, cultural politics, and terror of living Jim Crow. In Cardiff, he chronicled how a community of Arab, Somali, and West Indian seamen was formed by an imperialistic dialectic where rights and privileges enjoyed in the metropole were non-existent in the colonies. Taken together, all three studies offer a partial conception of an Anglophone Black Atlantic world as a diverse but interconnected socio-economic entity, with Bronzeville representing one nodal point along a vexed and dynamic circuit Drake traversed from the early years of the Great Depression to the dawning of African independence.

Well before the rise of Black Atlantic frameworks within the field of British Cultural Studies in the late 1980s, this forgotten trilogy within Drake's oeuvre lends itself to a social theory of black communities that was ethnographically informed by his observations of distinct relations and structures of power in, through, and against which black people lived, struggled, and formed separate life worlds. ${ }^{14}$ The careful distinctions he drew across these settings, however, did not obfuscate the extent to which "the story of Black Metropolis" was, "with minor variations, the story of the Negro in a number of other places." As he observed in the final paragraph of Black Metropolis, "the problems that arose on Bronzeville's Forty Seventh Street encircled the globe," informing, against racial constraints, the boundaries of Diaspora communities as well as "constant struggles for complete democracy." 15

Marking the centenary of Drake's birth, this examination begins the project of recovering one of the most underrated minds of the twentieth century by situating him within the community(s) that initially served to form him. Illustrative of the social theory of a black community outlined in Black Metropolis, Drake's lineage and formative years suggests that his was a cultural identity rooted in and routed through a series of racially constructed, semi-autonomous black life worlds, each held together by the collective desires of those made most vulnerable by the upheavals of capitalism and the caste-enforcing structures of segregation and colonialism in the post-emancipation Black Diaspora. ${ }^{16}$ From Virginia after the collapse of Reconstruction, Pittsburgh and the West Indies during and immediately after the First World War, and, finally, back to Virginia in early 1920s, Drake's movement through physical worlds and social realities differently situated reveal societies defined by constant struggles for democracy and institutions and organizations considered essential for survival in a world 
controlled by whites. In this regard, Drake's childhood experiences may have, at best, prepared him for this epic story of Chicago's Bronzeville and, in the very least, formed the basis for a conception of himself in later years as a product of the Black Diaspora and a unique journey that overlapped the culture, political economy, and history of multiple black communities in the Caribbean and United States. This central concept in Black Metropolis, therefore, is instructive to a chronicling of Drake's early life history, especially as it speaks to the creative ways in which his transnational identity and perspective was informed by the mechanisms black people developed for accommodating and resisting social disadvantage and alienation in segregated and colonial settings.

\section{Roots and Routes from Barbados to Virginia}

In a discussion of black religion in North America and the Caribbean, Drake articulated an awareness of himself as a "Pan-African Diaspora product," whose own lineage and life history made him a "partial insider" to multiple black communities. His father, John Gibbs St. Clair Drake, was born in Payne's Bay, Barbados in 1879, a fishing village located in St. John's Parish along the southwestern coast. ${ }^{17}$ Like much of the West Indies at the turn of the twentieth century, Barbados was a colony with a small, open economy in a worldwide capitalist system. His father's universe of operation within this setting was circumscribed by birth, because, as Drake explains, "he didn't come from the old free Barbadian population." Though "born free," Drake's father was the son of slaves, locked into the lower rungs of a society where, as C.L.R. James remarked of Trinidad at the time, "class and racial rivalries proved far too intense" for a black majority to overcome. In 1899, he graduated from the Academic Department of Harrison College, a Methodist-run secondary school established for the "poor and indigent boys of St. John's Parish." ${ }^{18}$ Undoubtedly aware that his aspirations would remain unfulfilled if he stayed on the island, he pinned his hopes for a better life on migration.

Like the "great mass of caste bound Negroes" that moved to Chicago to escape flood, famine, and hardship in the Mississippi Valley during the First World War, the migratory experience of Drake's father resulted from a combination of forces that made life in Barbados exceedingly difficult for a landless black majority. ${ }^{19}$ As tens of thousands of other West Indians, "there was no shortage of compelling reasons for black people - from the poor to the aspiring professional class - to escape these islands, insofar as they could." For Barbados in particular, a series of natural disasters, compounded by a colonial policy that privileged the interests of a small landholding oligarchy, created serious economic dislocation for those "least capable of withstanding it." When the Panama Canal boom, banana plantations of Central America, oil fields of Venezuela, sugarcane plantations of Cuba, and factories and steamship lines of industrializing America beckoned, Bajans, Jamaicans, Kittians, Trinidadians, and other islanders answered their call. ${ }^{20}$ With most going to other parts of the Circum-Caribbean and to cities in 
the northeastern United States, Drake's father was among a few to disembark in Norfolk, Virginia, a port city whose centuries-old Afro-American population came in by way of that very same water route that opens up to the Atlantic world. As Drake later recalled of his father's "apocryphal" arrival to Virginia, "he jumped ship ... sometime between 1903 and 1904." While "hanging around the docks," black Baptist preachers persuaded him to go to school at Virginia Theological Seminary and College in Lynchburg. Once there, he shed his Methodist cloak and discovered his life's calling, "to preach the gospel to the poor" and "set at liberty the captive." 21

While at the Virginia seminary, Drake's father met Bessie Lee Bowles. Eight years his junior, Bowles was a native of Staunton in Virginia's Shenandoah Valley. Once a "sleepy town" at the foot of the Blue Ridge Mountains, Staunton came to life with the coming of the Virginia Central Railroad in 1854. Like Chicago, where "men with money to invest discovered early that the site paid dividends," Staunton grew rapidly when "someone discovered a way to make the land pay." As Edward Ayers explains, "landlords, capitalists, immigrants, laborers, and large planters rushed in when opportunities beckoned," quickly transforming Staunton into a major center of commerce in Virginia's Upper Valley. ${ }^{22}$ The promise of wage work in vital industries connected to the railroad also fueled the migration of nearly two thousand newly emancipated slaves, mostly from within the state. Reflective of the menial place of black people in this burgeoning industrial economy, Drake's grandfather worked as a fireman on the Virginia Central Railroad and his grandmother was an "illiterate" domestic worker at the all-white Mary Baldwin Presbyterian Seminary for Women. ${ }^{23}$

Staunton was a completely segregated society wherein, as Drake observed of the South in general, "every white man" felt "impelled to protect every white family, clique, and church from Negro contamination." 24 With the rise of the eugenics movement and what C. Vann Woodward described as the falling away of effective restraint, Virginia's legislature moved to adopt a state constitution in 1902 that restricted the franchise. This was followed with a new statutory definition of a "colored person" being any persons with "one-sixteenth or more of negro blood," and a series of laws, passed between 1900 and 1918, that pertained to streetcars, residential areas, and prisons. More than just a throwback to what Ayers called "old-fashioned racism," the system of segregation that took shape in Virginia was to whites a badge of sophisticated, modern managed race relations which, by the turn of the century, even enclosed the railroad upon which so much of Staunton's growth and prosperity depended..$^{25}$ However, this system of segregation only reinforced black congregation and, in addition to serving as a critical "source of news and inspiration," the black church became an essential mechanism in widening the "horizons of ex-slaves." Though excluded from the Black Baptist clergy, black women like Drake's mother were free to pursue a course of higher education at the Virginia Baptist Seminary and College. ${ }^{26}$

Sometime in 1908 Drake's parents met at the Virginia Seminary, and in April of 1910 they were married. Nine months later Drake was born in Suffolk, 
Virginia where his father oversaw the spiritual well-being of some three hundred souls at the First Baptist Church in nearby Harrisonburg. ${ }^{27}$ Throughout his life, Drake considered himself a product of these communities and crosscurrents in the Black Diaspora. In the general flow of human history, his birth was the outgrowth of post-emancipation black migrations driven by economic dislocation and the boom of distant markets, which resulted, at the Virginia Seminary, in the convergence of differently situated black communities with roots in the centuries-long history of racial slavery in the Americas. That Drake would lead off his discussion of black migration to Chicago in the third chapter of Black Metropolis with the term "Black Diaspora" suggests, as his own heritage attests, a general awareness of the role migration plays in the correspondence between distinct physical worlds and social realities formed by subordination of black populations in North America and the Caribbean. ${ }^{28}$

\section{Religious Intellectuals against Race and Racism}

The institutional structure of the over five hundred churches in Bronzeville was the product of "external and internal forces" at work, engendering, among the populace, a sense of "pride in having something of their own" at the same time they "insisted on the extension of full economic and political opportunity." ${ }^{29}$ This ethnographically informed conception of the black church in Black Metropolis gives meaning to a community of Baptist missionaries and clergymen, who were, like Drake's parents, organized around the Virginia seminary at the turn of the last century. In addition to "fashioning" Drake's "father into a preacher" and "his mother into a schoolteacher," the seminary emerged from within a semi-autonomous black life world to produce a generation of religious intellectuals, who confronted, sometimes forcefully, symbols and structures of racial domination across the Black Atlantic. ${ }^{30}$ Though sharing a common theology with white Baptists, several graduates of the seminary turned to the Bible to lend support to historic struggles for freedom, identity, and self-determination, reflecting what Drake would come to see as a distinctive black response to the ideology of white supremacy in the modern world.

The Virginia Baptist Seminary was the first post-Civil War higher educational institution established in Lynchburg when interest in an "all black" theological school emerged at the 1886 meeting of the Virginia Baptist State Convention in Richmond. Following the collapse of Reconstruction, its founder Phillip Morris argued for the necessity of such an institution that would be "controlled by blacks" and "independent of whites." In 1887, the convention purchased six acres of land for this purpose, and the following year the seminary was incorporated. It was, as one observer remarked, "a school of the Negroes, by the Negroes, and for the Negroes." ${ }^{\prime 1}$ The Virginia seminary was committed to the idea that "Negro peoples were perfectly capable of higher intellectual pursuits" and "carrying on with their work without the white man always at their elbows." For this reason the seminary attracted the interest of many white Virginians, who considered it a 
"center of radical thought in regards to the race question" and its students "zealous proponents of the causes of the Negro American" and "African improvement and freedom." ${ }^{32}$ As Drake's genealogical connection to the seminary reveals, the reputations of its early missionaries and clergymen only served to bolster such suspicions.

Well before the establishment of the Virginia seminary, the primary gateway to Africa for black missionaries was the American mission movement. According to Drake, when black missionaries assumed a minor role in the evangelization of the "land of their forefathers" at the end of the nineteenth century, many had come to accept slavery as part of the providential destiny of African-descended people and Africa itself as a "heathen, dark, and benighted" place. However, in opposition to ideas that justified enslavement and, after emancipation, denied black people "the full status of free men and women," black religious intellectuals "turned to the Bible to 'prove' that Ethiopians were powerful and respected when white men in Europe were barbarians." 33 The belief that Africa had a glorious past and that the people of the Diaspora were destined to help redeem it was part of a compensatory mythology nurtured by the Virginia seminary and expressed in the missionary activities of John Chilembwe and William Sheppard.

A native of Malawi, then the British colonial protectorate of Nyasaland, Chilembwe graduated, according to Drake, just a few years before his father. Returning to Malawi from Lynchburg in 1900, he protested forcibly an exploitative system of plantation labor and the conscription of Africans into a war against the Germans. In February of 1915, driven by millennial expectations that the "Kingdom of God was at hand," Chilembwe seized on the opportunity of world war to lead a three-day armed rebellion against the British monopoly of power in Malawi. Though quickly suppressed, this initial blow against European colonialism reflected how one graduate of the Virginia seminary imbued Christianity with radical apocalyptical themes, believing that the "heavenly Father will help us" and "strengthen all weak brethren" in bringing about a "New Jerusalem." The irony of Chilembwe's legacy for Drake was that "freedom fighters in Central Africa came to know more about the [Virginia] Seminary than did black Americans." In the very least, they knew that the Virginia seminary uniquely formed the man "hanged for leading the Nyasaland rising against the British." 35

In addition to Chilembwe, Drake learned of how Sheppard travelled to Africa to participate in its uplift and redemption. Arriving from his native Virginia to the Congo Free State, now Zaire, in 1890, Sheppard spent two decades as a missionary among the Bakuba people where he became substantially defined by his militant opposition to the cruel and exploitative treatment of people in the Kasai District, principally by the Kasai Rubber Company during the reign of King Leopold II. ${ }^{36}$ As Drake recounts of Sheppard, "he would periodically visit our church and home" where, long after returning from the Congo, "he and my father's other missionary friends talked often of events and experiences in Africa." In 1923, when Drake was twelve years old, he attended a sermon delivered by Sheppard where he described the ordeal of his nine-month imprisonment in the 
Congo for reporting to the London Times how "King Leopold was a murderer." Believing, in "simple" theological terms, that "God let the Germans punish the Belgians for having cut African hands off down in the Congo," Drake recalled how his father was inspired by Sheppard to break rank with the Black Baptist Convention in refusing to raise money for Belgian war relief. ${ }^{37}$

Along with missionaries, the Virginia seminary also sent forth clergymen who, according to Drake, considered themselves "race men" and "defenders of black rights." This religious intelligentsia "took the words of the Magnificent seriously." They believed in the God of Daniel, in the God of black Christianity: benevolent and loving, but also an avenging God, a deliverer with a special concern for the oppressed. Through his father, Drake came to know these men as "able, ambitious," and "proud of their command of Greek, Latin, and Hebrew." They held firm to a providential view of history, believing that someday soon God would "cast down the mighty from their seats" and "exalt them of low degree. ${ }^{" 38}$ In the era of the Great Migration, they followed their congregations to northern cities and seized on the opportunity of war to highlight the shortcomings of democracy. If the black church was the "town hall" of a separate black community, then these ministers were its "publicists as well as exhorters." Free from white control and beholden only to their congregations, they spoke to the collective desires and racial constraints of the communities that produced them. Drake remembered how his own mother "idolized" three ministers in particular: James Robert Lincoln Diggs, William Henry Moses, and Junius Caesar Austin. ${ }^{39}$

Serving as president of Virginia Seminary when Drake's parents were students, Diggs gravitated into the Garvey movement during the war, becoming president of Baltimore's division of the United Negro Improvement Association in 1919. A contemporary of Chilembwe, Moses served as pastor of Mount Zion Baptist Church in Drake's mother's hometown of Staunton for over a decade, before migrating to Pittsburgh and eventually to Philadelphia where he helped establish the Colored Protective Association (CPA), which took as its mission the protection of black people from police brutality, unjust arrests, and racial discrimination. Following his congregation to Pittsburgh, Austin formed the International League of Darker Peoples (ILDP) and, with William Monroe Trotter, the National Race Congress (NRC) to petition, on behalf of black Americans, the international body of nations meeting at the Versailles Peace Conference. Against increased government surveillance and growing criticisms of Garvey from within the black community, all three clergymen rallied to the UNIA leader's defense. In his opening address at the Third International Convention of the Negro Peoples of the World in 1922, for example, Austin wrote Garvey into Old Testament prophecy, declaring "he is not a spy; he comes not as a traitor, nor a hired servant for foes, but appointed by God to lead us on to victory." Heralding him as "an angel sent by God to lead the folks," Moses encouraged black people "to follow Marcus Garvey." "40

This history of the Virginia seminary illustrates the transnational encounters of black missionaries with colonial Africa. As Drake recalled, "someone was 
always around who had just returned from the mission movement." ${ }^{41}$ They pointed to the abuses of colonial systems and "drew pictures of a contemporary Africa" that was "no longer painted in dark tones." These were the African experts of the day, men moved by their actual experiences in colonial settings to offer black Americans "a window onto Africa and the broader world." 42 While "the vindication of the race" would eventually pass into the hands of secular intellectuals after the First World War, it was, as Drake later noted, a task that first belonged to black missionaries, who, against the racial constraints of European colonialism, believed in "Providential Design and Biblically-sanctioned Ethiopianism." 43 The clergymen of the Virginia seminary provided modern Black Nationalism with a religiosity and emergent political movements a millennial meaning. In Garvey they imagined a prophet who was leading a worldwide black nationality onward toward the fulfillment of its providential destiny. Corresponding to a period in which, as Robin Kelly contends, "black intellectuals paid attention to the international situation and black peoples' place within it," Drake was aware of religious leaders who actually moved from the space of their independent churches to morally frame the "Negro Problem" as the problem of white supremacy shared by black populations worldwide. ${ }^{44}$

Virginia's early missionaries and clergymen collectively expressed a clear and necessary relationship between Christian theology and a life of activism. They were men that, according to Drake, articulated a counter-response to the denigration of black people and found objectionable Booker T. Washington's national leadership on "the grounds that he was too subservient and obsequious to whites." ${ }^{45}$ Corresponding to the consolidation of European colonial rule in Africa, and the mass migration of southern blacks to cities across the North, they emerged at the forefront of social movements, revealing of how "Negro Baptists thought of their institutions and organizations as part of a race church and their leaders as race men" committed to "fighting injustices and serving the Lord." 46 The connection of this generation of black religious intellectuals to early anticolonial and civil rights struggles was informed by a race consciousness and sense of Christian mission that radiated outward across the Black Atlantic from a separate Black Baptist universe in the segregated South at the beginning of the twentieth century.

\section{Black Migration and Diaspora-Making in Pittsburgh}

Chicago's Bronzeville was not the first urban black community Drake encountered. In 1916, when Drake was five years old, his family left Virginia and joined the mass migration of southern blacks to the North. As described in Black Metropolis, it was a moment in the history of Diaspora-making when over one million "caste-bound Negroes in the South stirred," leaving behind flood, famine, and economic hardship for new opportunities elsewhere. ${ }^{47}$ In the case of Pittsburgh, where Drake settled with his family, the Great Migration fueled the rapid growth of that city's black population, from 27,000 in 1910 to well 
over 80,000 by 1930. Like Drake's father's turn-of-the-century migration from Barbados, this historic movement of people corresponded to the economic boom of the steel industry and the limited opportunities for "surviving" and "getting ahead" in the South. ${ }^{48}$

Before World War I, Pittsburgh emerged as the industrial capital of the United States. With black men constituting upwards of 27 percent of the labor force by 1910 , factory work was central to the black experience in the city. As Joe Trotter and Jared N. Day observed of the "dismal failure" of the Great Steel Strike of 1919, they came first as strikebreakers, used by the steel companies to "break the back" of organized labor. In a very short period of time, however, southern migrants became a more reliable source of labor and industrial firms soon intensified their efforts to recruit more black workers. ${ }^{49}$ In Pittsburgh, as in other cities across the country, a mostly southern agrarian population entered a modern industrial age and laid the foundation for a new Diaspora community.

Following the rail lines along the Atlantic corridor, these new arrivals came to Pittsburgh by the tens of thousands, transplanting with them entire communities. Like several other Virginia clergymen, Drake's father followed his congregation to Pittsburgh where jobs in wartime industries were opened up to black people. As Drake explains of his experience during this period, "when the great migration northward began ... my father and J.C. Austin followed parts of their congregations from the Virginia Tidewater to a place where money was flowing." In Pittsburgh, Austin became head of Ebenezer Baptist Church and Drake's father assumed the pastorate of Bethany Baptist Church, settling with his family in the mostly white working class neighborhood of Brushton. ${ }^{50}$

Like Chicago, Pittsburgh's "color line was tightly drawn" around housing. Legal and extralegal measures, which included a combination of creative zoning laws, a large and energetic chapter of the Ku Klux Klan, and local law enforcement, reinforced a system of de facto segregation that confined the majority of blacks to the most run-down areas of the city ${ }^{51}$ Against white resistance, Drake's father "insisted upon buying a house where black people had not lived before," and, true to his militant spirit, "threatened to shoot anybody who tried to deface his property." That Drake's family lived in Brushton suggests that residential segregation in Pittsburgh was, as in Chicago, less rigid than in the South. "Though evidence of democracy of work," the breaking of the color line in Pittsburgh was not without conflict and the very real threat of violence. ${ }^{52}$

In Pittsburgh, Drake's family lived in a mostly white working class community, but they were integrated into a dynamic religious culture in the all-black Hill District of the city where evidence of "an interest in praising the Lord was everywhere." ${ }^{33}$ In addition to the over five hundred members of his father's church, the Hill was home to some forty-five other churches that emerged during the era of the Great Migration. Along with several Baptist churches, these included numerous "holiness" storefronts, several AME and AME Zion churches, a Presbyterian church, an Ahmadiya Islamic Mission of America, and even a black millenarian sect in the form of Noble Drew Ali's Moorish Science 
Temple of America (MSTA). With twenty-five of these institutions claiming memberships of well over 12,000 people in 1920 , the church was, in all of its varied denominations, the essential organizing institution around which a black community formed. In Drake's own life history, the church was also where he got his "intellectual start." As he explains of this period, "I saw this institution from the inside and mastered a body of knowledge, which would prove valuable to me when I made the study of religious behavior my special subject." 54

The black church was the most powerful single institution in the Hill, existing in cooperation with other institutions that gave rise to a class of black professionals, politicians, and civic leaders, who, along with ministers, emerged as influential figures within the community. The Pittsburgh Courier newspaper, founded by Robert Vann, reflected a black mainstream, and banks, real estate and insurance companies, barbershops, beauty parlors, and funeral homes all formed the basis of a closed market economy. From their pulpits, black ministers encouraged the support of "racial businesses" by preaching on the "value of the double duty dollar" to "advancing the race." In this spirit, Drake's father, along with Austin, established the Home Finders League (HFL) to get new arrivals to the city "settled and signed up on the membership rolls of the NAACP." the same time, the HFL was also connected to other business ventures that drew from the savings of nearly 5,000 depositors to purchase property in the city worth well over 300,000 dollars. By renting its properties back to migrants and their families, the HFL created opportunity where none had previously existed. In addition to meeting the most basic needs of new arrivals, the HFL shared a vision of racial uplift that "measured progress since slavery partly in terms of the positions of power and prestige that Negroes attained in the business world." ${ }^{56}$

Like Bronzeville, the Hill also drew a clear line between the shady and respectable, the sporting world and the world of churches, clubs, and polite society. As Drake remembers, this was a "fast moving period in my life;" it was the era of "motion pictures" and the "widespread" use of the "plane, radio, and automobile." 57 It was also a time of "card playing, dancing, and the policy game"; professional black baseball and boxing; nightclubs and afterhours spots. These recreational outlets made the Hill a "dynamic, thriving, and bustling place" described by one long-time resident as "Pittsburgh's Little Harlem" and another as "the crossroads of the world." In sociological terms, it was suggestive of how black people "treasured their inalienable right to pursue happiness" against the social reality of racial discrimination and de facto segregation. ${ }^{58}$ Although black migrants made significant inroads into Pittsburgh's industrial workforce, they remained "disproportionately represented in servant work" and did a "little above their proportionate share of manual labor." Mostly concentrated in menial positions, black people also faced an ongoing pattern of "last hired and first fired." While black women gained access to factory work, many more were locked out of the city's manufacturing industries. As was the case in the nineteenth century, most black women in Pittsburgh, as much as 90 percent in 1920, remained tied to jobs in the domestic and personal service industry. Such conditions forced 
some to return to the South and the local chapter of the Urban League to outright discourage further migration to Pittsburgh, citing "the difficulty of [even] finding work." ${ }^{59}$

These circumstances mirrored other aspects of black life in Pittsburgh. Only a handful of schools permitted black and white students to attend together, and well up and through the Great Depression not a single black teacher was to be found in the entire public school system. ${ }^{60}$ From 1917 to 1923, Drake was one of only a small number of black children to attend an integrated public school. As he remembers of his experience, "it was here where my earliest attitudes toward racist practices were formed." He recalled "at least one fight" with a white classmate over "being insulted about the color of [his] skin"; then there was the problem of black exclusion from Brushton's only library, as well as from the floor seating in this community's only theater. From public accommodations and large commercial establishments to restaurants, swimming pools, skating rinks, hospitals, and cemeteries, black people in Pittsburgh were either excluded from service altogether, or offered provisions on a segregated and unequal basis. ${ }^{61}$

Discrimination in employment, the deprivations of the ghetto, and the denial of certain civil liberties resulted in widespread dissatisfaction among black people, which found meaning in local protest campaigns. Led by Austin, the local branch of the NAACP pushed for the hiring of more black teachers in the city's public school system, the passage of new state civil rights laws, the termination of police harassment, and an end to workplace discrimination against black workers. ${ }^{62}$ From his pulpit at Bethany Baptist, Drake's father worked to build a black political base to press for access to better housing, employment, and education. Believing it was "better to elect a Negro generally speaking than any white man," he supported Vann's use of the Pittsburgh Courier to mobilize a politically independent voting block against the commanding sway of the Republican Party's patronage system. Identifying white working class racism as the principle cause of black economic oppression, Reverend Drake encouraged his congregation to "believe in the power of their own numbers" to become "strikebreakers" and form independent labor unions along racial lines. ${ }^{63}$

In 1923, the HFL "went bust" and, having "stood for the notes," Drake and Austin fell into disfavor with the city's Baptist hierarchy, as well as with many members of Bethany and Ebenezer Baptist Church. Soon thereafter, Austin left Pittsburgh "somewhat under a cloud of suspicion" and resettled in Chicago where he became pastor of Pilgrim Baptist Church, the largest black church in the city's South Side. Under the pretext of attending to his ailing mother, the Reverend Drake was granted an "indefinite leave of absence" from his pastoral duties at Bethany Baptist and in October of that year returned with Drake to Barbados; Drake's mother, meanwhile, left for Staunton to stay with her mother during their yearlong absence. ${ }^{64}$

Between 1923 and 1924, Drake travelled throughout the West Indies, visiting Barbados, the Virgin Islands, Antigua, Guadaloupe, Granada, and St. Lucia. This was, as he explains, his "first contact with a black society," impressing on 
him an appreciation for the "cultural differences between Afro-Americans and West Indians" and "stimulating" his earliest "interest in anthropology." ${ }^{65}$ Drake's father, on the other hand, was moved by the realities of an economy in rapid decline since his own departure twenty years before. The rigidity of this island's economy created serious economic dislocation, and massive inflation impoverished the populace. Many returnees, who thought they had earned enough money elsewhere to make a reasonable living at home, soon discovered that they, once again, had to "take to the high seas." According to Drake, his father was "appalled by the poverty of the people of the Indies" and "incensed by the attitudes of the British ruling class," which "developed" into a full-blown "antagonism toward the Empire." On his return to Pittsburgh in 1924, Drake's father joined the Garvey movement, seeing in it the most expedient course "for the freeing of Africa from imperialist domination" and creating "an independent West Indian federation." $" 66$

Soon after his return to Pittsburgh, Drake's parents divorced. At thirteen years old, Drake returned with his mother to her native Staunton. From this moment forward, the Reverend Drake existed only as a "role model" and "absent hero" in his son's imagination. The reason, according to Drake, was that his father "resented" that he "chose to go with" his "American Negro relatives" instead of "cleaving" to his "West Indian side." ${ }^{67}$ Never again did Drake lay eyes on his father. Instead, he bore witness from afar to his meteoric rise in the leadership structure of the Garvey movement, becoming International Organizer of the UNIA in 1926 and then returning to the South in 1927 to become headmaster of Liberty University, a UNIA-sponsored college that, according to Drake, "eked out a precarious existence" in Jamestown, Virginia. As Drake would later learn from his father's second wife, Reverend Drake eventually returned to his Methodist roots and kept abreast of his son's activities through newspaper clippings. Less than a year before his father's death in 1959, Drake learned that he "took great pride in the fact that his boy was out there [in Ghana] helping Nkrumah vindicate Garvey." 68

\section{Shades of Segregation in Virginia}

The Staunton of Drake's youth was a Jim Crow society characterized by a system of laws that made the black community aware of itself. With his mother, Drake lived with his grandparents where the most immediate change he experienced was a descent from the relative security of Baptist parsonages to the less-than-secure "lower middle-class" lifestyle of Staunton's laboring masses. Although Drake described this as a "rather exciting period in his life," his learning of "what it meant to be a Negro" was also "rather frustrating." As he recalled, "we [the black community in Staunton] were segregated, but it was not the same harshness of the Deep South-Mississippi, Alabama, or Louisiana." Though Staunton was a "divided society," racism seemed more of a "nuisance" than anything else. In some instances, it demanded a degree of cunning to over- 
come, like on those occasions Drake enlisted his grandmother to secure books for him from Mary Baldwin's "whites only" library. On other occasions, it called for open opposition. For example, in a letter to the editor of Staunton's daily newspaper, Drake condemned the practice of referring to "black women ... by their first names, rather than by Miss or Mrs." To his surprise the paper changed its policy. "Spurred on" by the "taste of victory," the young Drake became, at this moment, "a habitual protester," unwilling to conform to or remain silent about segregation's humiliations. ${ }^{69}$ That the local newspaper abandoned this practice suggests a greater degree of flexibility in Staunton's system of segregation as compared to that of the Deep South.

At Staunton's Booker T. Washington High School, Drake recalled never feeling socially disadvantaged. "We," referring to himself and other black students, "were able to pass" the "all white and very fine looking" Stonewall Jackson High School ... on the way to "our little, underfinanced cracker box high school ... without giving much thought, if any, to Jim Crow." At Booker T. Washington, Drake thrived, remembering how his "classes were lively, basketball exciting, and the annual Negro history week inspirational." He also benefited from the presence of black teachers, who were "educated, highly motivated, and endeavored to create academic programs equaled to, or better than those at local white high schools." According to Drake, most of his teachers had come to Staunton from outside the South, bringing with them a clear conception of black education based on ideas and sentiments "scavenged from writers of the Harlem Renaissance."

In 1927, Drake left his home in Staunton to enroll at the Hampton Institute in Hampton Roads, Virginia. In contrast to Booker T. Washington, Drake encountered a school in revolt against itself and a system of segregation that, since its founding in 1868 , required black students, many of whom by this time had come from outside the South, to accept a social order predicated on ideas of black racial inferiority. At issue was the very meaning of higher education for black people and the moral authority of Hampton's third white principal, James E. Gregg, who attempted to walk a fine line between the competing expectations of ardent segregationists and a generation of students that insisted on training that would serve to "advance the race." ${ }^{\text {"11 }}$ Though initially met with stiff resistance, widespread condemnation, and severe reprisals, the organized efforts of black students to take ownership of their education signified the passing of one era, marked by the hegemony of the Hampton Idea, and the beginning of another that reflected the higher aspirations of black youth, who, like Drake, arrived to Hampton in the era of the New Negro.

Whereas past regimes at Hampton drew students from poor agricultural regions in Virginia and neighboring states, efforts to transform the school into an actual college by the mid-1920s was dependent on attracting a larger number of black high school graduates from outside the South. As one such student remembered, there was "about one thousand students that came from about thirty states and several foreign countries in the Caribbean and Africa." Of this number, over four hundred arrived from outside Virginia well prepared for advanced aca- 
demic study at the collegiate level. ${ }^{72}$ In the diversity of their regionalisms some were distinguished as the children of a rising black middle class, many of whose reputations on campus were fixed to the accomplishments of their families. There was John Spaulding, who was the son of Charles Spaulding, founder of the North Caroline Mutual Life Insurance Company. A longtime supporter of the NAACP and "a paramount figure in the world of business," Spaulding was once held up by Du Bois as a model of black potential. John Sengstacke was also Drake's contemporary at Hampton. The nephew of Robert Abbott, Sengstacke was heir to a publishing empire that included the Chicago Defender, the nation's leading black newspaper at the time. ${ }^{73}$

African students also arrived at Hampton during this period through an integrated network of industrial philanthropy and mission schools. As one student recalled, "there was Sumner from Sierra Leone, Caluza from South Africa, Kagwa from Uganda, and Koinange from Kenya."74 Benjamin Kagwa and Peter Mbiyu Koinange were particularly important for their place in the hagiography of African independence. A member of the Bagauda Tribe, Kagwa's family was favored in the court of King Edward Mutesa. His grandfather, Apolo Kagwa, converted to Christianity and became a staunch defender of the Anglican faith. When a civil war pitted Anglicans against Catholics in 1888, Kagwa's grandfather led the Anglican faction, gaining influence and prestige with British colonizers and the Bagauda elite. When Kagwa arrived to Hampton, he did so as the beneficiary of his grandfather's long-standing connection to the missionary apparatus of British colonial authority in Uganda. Described by Drake as "second only to Jomo Kenyatta" in "prestige" and "influence," Koinange came to Hampton from a mission school in Kenya on a scholarship from the Phelps-Stokes educational commission. The son of a Kikuyu chief, Koinange's presence at Hampton sensitized Drake and other students to Kenya's problems under white settler rule. From Koinange, Drake specifically learned about the land struggle among the Kikuyu, the effects of which "made" him a "partisan in the African's struggle for getting the land back." 75

In the same way that Koinange stimulated his interest in African affairs during this period, Drake believed that sustained contact with African Americans at Hampton may have had played a role in steeling "the resolve of African students to struggle for independence in their own homelands." Arriving to Hampton less than a month before the student strike, Koinange saw, according to Drake, "black students close down a powerful educational institution." The idea that "vigorous nonviolent pressure" could effectively force change was one, Drake believed, not lost on Koinange and other Africans at Hampton. ${ }^{76}$ As a site of Black Atlantic convergence, Hampton marked Drake's earliest direct contact with African people. In the decades following his graduation, Drake would move with Koinange through a series of anti-colonial communities in England, Ghana, and Kenya. Given the history of Hampton Institute's early regimes, the irony of this critical period of Diaspora-making was that it was underwritten by missionary and industrial philanthropy. 
With the widening of racial segregation across Virginia, Hampton students increasingly came to experience the "mold" of education first "set down" by the school's founder Samuel Chapman Armstrong as sinister in its intentions. If racial integrity laws in the state were bound up with the eugenicist movement, then, as Drake explains, black students at Hampton were deeply self aware and sensitized to the social implications of this racial logic. On reflecting on the state of anthropology in the 1920s, Drake remembered how he and many of his peers "resented the idea of a white man ... measuring students' heads, to check under their arms with a color top, and to ask questions about the skin color of their parents and grandparents, and to inquire how 'white' or 'Indian' the family traditions claimed they were. We radicals," Drake explains, "were hostile to those ideas most closely associated, in our minds, with paleontology and anthropometry." In short, they seemed "extremely racist" and "we (Hampton students) were firm believers in 'Progress." 77

The persistence of the Hampton Idea in this heightened climate of race consciousness made the school's third white principal vulnerable to attack. This was especially the case with student perceptions of Hampton's long-standing disciplinary regime. Placing blame for its continuance squarely at his feet, one student reported to Du Bois that "Dr Gregg and all of his co-workers have spent more time in trying to teach the Negroes their places ... than they have in trying to give them an education that would make them men and women capable of facing the world and its great problem." Another maintained that Hampton "was run more like a disciplinary barrack or reform school ... than an educational institution attended by the sons of free men and women." Gregg was clearly viewed by the very students he sought to attract as a symbol of the past, sharing with his predecessors, as Drake particularly believed, a genuine commitment to "character building among Negroes." 78

Following a public controversy that erupted around a performance of the scantly clad all-white Denishawn Dancers before an interracial audience in Hampton's Ogden Hall, Gregg expended considerable energy appeasing those interests upon whose satisfaction the survival of the college depended. Gregg implemented measures to "bar the public from attending social and cultural events" on campus without his expressed permission and instituted a "fine of ten to thirty-five dollars for any person who ... refused to sit in separate seats." Through these actions, Gregg hoped to assure public that Hampton would remain an "institute in every sense of the word and discourage any social mingling of the races under circumstances which could," as he believed, "lead to future embarrassment on either side." 79 In response to these measures, students went on strike less than a month after Drake arrived. At issue, according to Drake, was Hampton's "largely white faculty and administration," who reflected the continued "presence and influence of the old post-Civil War, New England school mistresses." In Drake's opinion, they still "believed" they were on "a civilizing mission among Negroes in the South." ${ }^{\text {80 }}$ They simply could not see that the New 
Negro spirit had finally arrived at Hampton. As Drake explains, it was a moment that spontaneously gave rise to a movement.

It happened innocently enough one Saturday night . . . when the seniors, who were sitting in the back of Ogden Hall with their girlfriends, demanded that the lights be turned off. They started singing, "Lights out, lights out," and the dean of women, who was a white New England woman, late middle-aged, came around and said, "What's all this disorder about?" The seniors wanted to know why the lights were on. She said, "Because I understand there has been immorality going on back here" ... The students got up and stalked out . . . Later that evening, a group of very enterprising young men went around and said, "Tomorrow don't sing any spirituals." At noon Sunday, Principal Gregg came to the dining room expecting to hear the Lord's Prayer. Instead, he discovered students singing "Oh freedom, oh freedom, over me yet, before I'll be a slave I'll be buried in my grave and go home to my Lord and be free." When the students refused, for a second time, to sing spirituals during a visit from Sir Gordon Guggisberg of the Gold Coast, Gregg took measures to punish the offenders. ${ }^{81}$

The act of "turning on the lights" in Ogden Hall violated, according to Drake, a long-standing privilege that allowed for seniors in the Academic Department to take young ladies to certain evening exercises. Du Bois interpreted it as a "direct insult" to the student body, and "especially to the womanhood of the Negro race." ${ }^{\prime 2}$ However, the litany of student demands that soon followed did not rest on this incident alone, but embodied a revolutionary fervor to transform Hampton into an institution that reflected the insistence of black youth for respect and recognition.

Of the some sixty-four grievances sent to Gregg and his administration was, as Drake remembered, the call for the hiring of "more Negro teachers" and administrators, higher academic standards, the termination of "racist and unqualified faculty," student representation in school governance, an end to Hampton's disciplinary regime, and a "general amnesty" for all those involved in the strike. Seeing the "lights on" policy as a particular insult, they also called for its termination. ${ }^{83}$ Agreeing to suspend the strike on Gregg's promise to give their grievances a fair hearing, students returned to class. Without addressing any of the students' demands, however, Gregg only promised to pursue a course of action that would "prevent a reoccurrence of disorder." He assured that "young women" and "new students," the last of which included Drake, "would not be held responsible for acts of deliberate subordination"; those students who "absented themselves from classes and work routines" would be "put on immediate probation until the Commandant of Cadets determined their satisfactory conduct 
and right of spirit"; finally, those guilty of "inciting others to insubordination" were to be "immediately expelled." As Drake recalled, "the administration's insistence upon expelling the leaders of the strike" forced "a second strike, with the slogan 'Not a one of us goes!' We insisted," he explained, on "the amnesty of the leaders." $"{ }^{\circ}$

With the resumption of the student strike, Gregg took draconian measures by closing the school down and sending students home. "Explaining that the work of the school could not be carried on with students who are disorderly and lawless," the principal made it clear that "Hampton wanted no students save those who gave evidence of their sincere purpose to cooperate with officers and teachers in maintaining peace, order and the mutual friendliness without which the school could not be successful." While promising to reopen the school in a month's time, Gregg notified the students that they would have to reapply for admission and sign a loyalty oath swearing their obedience and cooperation toward these ends. Altogether, over four hundred students went home, sixtynine received suspensions, and hundreds more were placed on probation. Of the twenty students that made up the Protest Committee, four were expelled. ${ }^{85}$

In their efforts to transform Hampton by overturning the Hampton Idea, students failed to draw widespread support. In fact, a black mainstream seemed to endorse Gregg's handling of the affair, condemning outright the actions taken by students. The Baltimore Afro-American, for example, criticized strikers for allegedly "placing more emphasis on social relations with coeds than upon a liberal education." In contrast to its bold denunciation of the climate that gave way to a racial integrity law in 1926, the Norfolk Journal and Guide insisted that such a display was demonstrative of "ingratitude" among "Negro youth today who were" apt to "look a gift horse in the mouth." port for Gregg none rang louder than those of the parents, who, as evidenced by the words of one distraught mother, gave their unquestionable allegiance to the principal.

Please read this note to my son and tell him not to send me anymore telegrams unless signed by you. Mr. President, I am a hardworking woman with an invalid husband and I am not a young woman, but trying to work and give my boy an education ... I mean for him to be governed by you and only you, for I do not know what my boy is raving about and I don't want to know, but want to keep him in school, the place and the only place I mean to send him. ${ }^{87}$

This broad support for Gregg drew the very life's blood from the student strike, returning moral authority to a principal beholden to forces opposed to "the higher education of Negroes" in the South. Even Du Bois gave into defeat, observing in his final analysis of the strike that "slowly the students are drifting back. Their parents for the most part have joined with Dr. Gregg and the Hampton faculty to 
bend them into submission. The strike has thus failed and the compelling heroes at Hampton are free to proceed with the Hampton Idea." 88

Though victorious in battle, Gregg and his administration eventually lost the war. With most of the students back on campus, save for those few who were expelled, Hampton's Board of Trustees began to implement many of the student demands. Although Drake continued, in later years, to refer to "his Hampton" as a "vocational school," the last of many reforms to liberalize the curriculum were finally implemented at the end of his second year. ${ }^{89}$ With increasing enrollment in the college division, Hampton no longer accepted students who had yet to complete a basic high school curriculum. In addition, it disbanded the trade school program first begun by Armstrong. In a shocking turn of events, the Board of Trustees also asked for Gregg's resignation in 1929, as well as that of the Disciplinary Dean and Commandant of Cadets. Citing continued unrest between the faculty, administration, and students, the Board of Trustees found it in the best interest of Hampton University to move forward without Gregg. Though not specifically given as the reason, the Board was clearly concerned with the expressed resentment of students toward the "very policies and social philosophy that underlay the recent endowment campaigns." 90

Gregg's departure prepared the way for President George Phenix, who promised a "new era" at Hampton. Serving as vice principal under Gregg, Phenix was described by Drake in the Script as "a heroic pioneer for the race" and a "restorer of the peace" at Hampton. ${ }^{91}$ In the three years following the student strike, Drake flourished, coming under the influence of black professors, who demonstrated for him that scholarly pursuits and political commitments did not have to be mutually exclusive endeavors. There was Nathaniel Dett, who headed up Hampton's Music Department. Dett's influence on Drake was evident in an essay he wrote while chief editor of the Hampton Script. In response to that "class of Negroes" who, in his view, "wished to slough off the spiritual as a vestige of an unpleasant experience," Drake called Dett's efforts to keep the spirituals alive "noteworthy" and encouraged the singing of more spirituals as essential to "building a spiritual life" at Hampton and engendering a "respect for black culture" among its students. ${ }^{92}$ The botanist Thomas W. Turner arrived to Hampton from Howard University in 1922. As a biology and education major, Drake took classes with Turner and worked for him as lab assistant. From this experience he came to know Turner as "an outstanding Catholic layman," who earned his father's admiration for always "protesting against segregation in the Catholic Church." As president of the Federated Colored Catholics (FCC), Turner's "feisty fighting" influenced Drake. ${ }^{93}$

The person to most influence Drake at Hampton was Allison Davis. Possessing what Drake described as "larger horizons than Hampton itself," Davis arrived from Harvard in 1926, bearing "the message of Irving Babbit's New Humanism." In the culture wars of the 1920s, Drake remembered how Davis made a reputation for himself by deprecating, in poetry and prose, the influence of the cultural New Negroes as vigorously as Babbitt condemned romantic 
writers of the eighteenth and nineteenth centuries. In an essay for the Crisis entitled "Our Negro Intellectuals," Davis criticized the works of Countee Cullen, Claude McKay, Langston Hughes, and James Weldon Johnson for representing "the most pernicious influence in Negro society." In their allusions to "African jungles," Davis believed they invoked a primitivism that implied "the Negro" as "bestial" and devoid of the "self respect" necessary to challenge and overcome the effects of "slavery and segregation." Revealing of Babbitt's conservative influence, Davis called for a more forceful doctrine of moderation and restraint, one that would promote respect and recognition and, at the same time, address the economic and social conditions of the black laboring masses. As Drake understood it, Davis's criticisms were reflective of those black intellectuals who were very self-conscious about what obligations they had to the masses ... "We, as their students," he maintained, "shared these concerns as members of that tiny college-trained group that had emerged in the sixty odd years that had elapsed since slavery was abolished." While many educated blacks were "running away from the South," Drake remembered how Davis called for black intellectuals to "return to the bosom of the masses." This was "revolutionary talk," the effects of which "forced us, as students, to straighten-up our heads." "95

In the years following the student strike, Drake served as editor of the Hampton Script, president of the student government, and ran the college chapter of the Association for the Study of Negro Life and History. As editor of the Script, he came to "learn" what "a powerful force the press was for progressive change" and took to heart "the advice of friendly professors," who pointed out to him their "concern for the proper use of language and format ... if our ideas were to win a hearing in high places." ${ }^{.96}$ Drake's own ideas were informed by his increasing awareness of the black condition behind the "cotton curtain" of the Deep South. As he explains, "it was not until I visited Tuskegee as a representative of the student council that I first experienced the segregation, which impacted Booker T. Washington." In contrast to the "mild system of segregation in Virginia," Drake's brief sojourn into Alabama in the age of Scottsboro and sharecropper rebellions opened his eyes to a more entrenched and violent form of Jim Crow. ${ }^{97}$ Revealing of how he sought to "function as a campus radical," Drake took to the pen to articulate a very practical purpose for Hampton. Against the charge by Arthur P. Davis that Hampton students were of "low quality, unscholarly, and too lazy to benefit from the rigorous intellectual pursuits," Drake argued that vocational education has a place in "building up an atmosphere of scholarship and culture." For "the race to succeed," he argued, "a mastery of the fundamentals of life was necessary." Southern society, with its history of slavery and Jim Crow segregation, was responsible for the condition of black youth, and Hampton, as an independent black school, was best suited for their advancement. ${ }^{98}$ In Drake's view, it was incumbent for black intellectuals to return to black communities in the South and render service to the masses with the commitment of making a more complete democracy in the United States a reality. 


\section{Conclusion}

The migrations embedded in Drake's early life history linked multiple black communities across a shifting geography of race. From the island colony of Barbados where power, influence, and wealth was concentrated among a few to the separate universe of independent Baptist institutions in the Virginia Tidewater after the abolition of slavery; from the Hill District of Pittsburgh where a southern population encountered modernity in the era of the Great Migration to the declining economies of the British West Indies after the First World War; and finally, back to Virginia with the coming of the New Negro and, eventually, the pressures of the Great Depression itself. Each represented a composite part of the Black Diaspora and, much like Bronzeville of Black Metropolis, correlated with what Drake experientially came to know as differentiated systems of social advantages within which black people organized a separate life world and struggled against the deprivations and impoverishment of discrimination.

Corresponding to the rise of racial segregation and colonialism in his own time, Drake became aware of religious and secular intellectuals, who moved through separate black institutions to articulate a counter-response to the problem of racial domination in the United States, Africa, and the Caribbean. Drake himself would carry these experiences into efforts on the part of black students to overthrow a philosophy of education at Hampton Institute, which, since the aftermath of the Civil War, relegated black people to a subordinate position in southern society. This generation of students represented a unified and resolute group of black youth who, en masse, refused to bow to symbols of segregation in Virginia. Like Drake, they too rode the crest of a rising tide of a black militancy uniquely informed by black migrations and the promise of democracy after World War I with the determination to remake Hampton into a space more consistent with their desire for racial congregation, self-determination, and independence.

In the decade following the publication of Black Metropolis, Drake moved away from community studies as a mode of sociological investigation, preferring instead to carry out, within the context of the sociology of knowledge and intellectual anthropology, comparative examinations of race and culture across Africa and the African Diaspora. ${ }^{99}$ This shift corresponded to his physical relocation to Africa in the era of independence, the Caribbean during and after the period of West Indian Federation, and to Roosevelt and Stanford University where he pioneered the establishment of African and Black Studies programs. Despite these turns, however, Drake's oeuvre remained unified by the fact that he undertook both scholarly work and activist commitments with a view toward producing knowledge uncompromisingly aligned with the promotion of social justice and human liberation rooted in the expressive claims of pre-colonial and modern black folk communities he encountered "here and there" in Africa and the Black Diaspora. Within and beyond Black Metropolis, therefore, this orientation is instructive to understanding Drake's own life history and identity as one shaped by a series of separate black life worlds as well as distinct struggles for greater democracy in the age of American empire. 


\section{Notes}

1. Andrew Salkey, "Landscape after Retirement (a poem for St. Clair Drake)," St. Clair Drake Papers, Box 4, Folder 5, Schomburg Center for Research in Black Culture and History, New York Public Library.

2. St. Clair Drake, "The Black University in the American Social Order," Daedalus 110, no. 3 (Summer 1971), 883.

3. Sutton Griggs, Imperium in Imperio (Cincinnati: Editor Publishing Co., 1899).

4. St. Clair Drake and Horace Cayton, Black Metropolis: A Study of Negro Life in a Northern City (Chicago: University of Chicago Press, 1945), 744.

5. Ibid., 396, 121-122.

6. This idea that racial prejudice would give way to integration is drawn from Robert Parks's race relation cycle theory, see Robert Park, "Human Migration and the Marginal Man (1928)," in Theories of Ethnicity: A Classical Reader, ed. Werner Sollers (New York: New York University Press, 1996), 156-167.

7. James McKee, Sociology and the Race Problem: The Failure of a Perspective (Urbana and Chicago: University of Illinois Press, 1993), 214-216; for a discussion of this critical distinction between race and ethnicity as informed by Black Metropolis, see Faye Harrison, Outsider Within: Reworking Anthropology in the Global Age (Urbana and Chicago: University of Illinois Press, 2008), 72 .

8. The explosion of community studies on race relations began in the mid-1930s with an emphasis on the South, see, for example, Charles S. Johnson, Shadows of the Plantation (Chicago: University of Chicago Press, 1934); John Dollard, Caste and Class in a Southern Town (New Haven: Yale University Press, 1937); Hortense Powdermaker, After Freedom: A Cultural Study in the Deep South (New York: Viking Press, 1939); Allison Davis, Burleigh R. Gardner, and Mary R. Gardner, Deep South: A Social Anthropological Study of Caste and Class (Chicago: University of Chicago Press, 1941).

9. Henri Lefebvre, The Production of Space (Malden, MA: Blackwell, 1991); Loïc Wacquant, Prisons of Poverty (Paris: Raison d'agir, 1999); Urban Outcasts: A Comparative Sociology of Advanced Marginality (Malden, MA: Polity Press, 1998); John L. Jackson, Jr. Harlem World: Doing Race and Class in Contemporary Black America (Chicago and London: University of Chicago Press, 2004); and Sudhir Vinkatesh, Gang Leader for a Day: A Rogue Sociologist Takes to the Streets (London: Penguin Books, 2008).

10. Drake states he "wrote all of Black Metropolis with the exception of one chapter," but "Cayton criticized them all," see Drake, letter to John Bracey, 19 January 1975, files of John H. Bracey, author's possession; Cayton became involved in a dispute with Warner over the authorship of Black Metropolis, informing him that "since Drake wrote most of Black Metropolis, and he [Cayton] raised funds for the book, wrote a chapter [Chapter 6: Along the Color Line], and assisted Drake in the layout, only their names should appear on book; he concluded by insisting that Warner not appear as an author since he did not contribute enough to be considered as such, see Horace Cayton, letter to Warner, 10 January 1944, Box 5, Folder 28, St. Clair Drake Papers.

11. For Drake's reflections on the Black Metropolis period in his life, see Benjamin Bowser, Interview with St. Clair Drake, "Studies of the African Diaspora: The Work and Reflections of St. Clair Drake," Sage Race Relations Abstract 3, no. 14 (August 1989), 10-15; see also George Clement Bond, Interview with St. Clair Drake, "A Social Portrait of John Gibbs St. Clair Drake," American Ethnologist 14, no. 4 (November 1988), 770-72; St. Clair Drake, "Reflections on Anthropology and the Black Experience," Anthropology and Education Quarterly 9, no. 2 (1978), 94-97.

12. Harrison, Reworking Anthropology, 72.

13. See Allison Davis, et. als., Deep South; although Drake was not listed as an author of this study, he was an integral member of the research team in Mississippi, see St. Clair Drake, "In the Mirror of Black Scholarship: W. Allison Davis and the Deep South," in Education and the Black Struggle: Notes from the Colonized World, ed. Institute of the Black World (Harvard Educational Review, Monograph 2, 1974), 42-54; for his study of Cardiff, Wales, see St. Clair Drake, Values, Social Structure, and Race Relations in the British Isles (Dissertation: University of Chicago, 1954).

14. Drake's local study of black communities in Mississippi, Chicago, and Cardiff points to a Black Atlantic perspective well before Paul Gilroy and a handful of other scholars (Stuart Hall, Kobena Mercer, Hazel Carby, Joseph Roach) ushered in a transnational, interdisciplinary project within black British cultural studies, see Paul Gilroy, The Black Atlantic: Modernity and Double Consciousness (Cambridge: Harvard University Press, 1993); for a discussion that historicizes Black Atlantic perspectives in British cultural studies, see Kwesi Owusu, "Charting the Genealogy of Black British Cultural Studies," in Black British Culture and Society: A Text Reader, ed. Kwesi Owusu (New York: Routledge, 2000).

15. Drake and Cayton, Black Metropolis, 755, 767.

16. I see this discussion as responding to Frank Guridy's call for scholarship on the postemancipation Black Atlantic world, see Frank Andre Guridy, Forging Diaspora: Afro-Cubans and African Americans in a World of Empire and Jim Crow (Chapel Hill: UNC Press, 2010), 4-7. 
17. For Drake's reference to himself as a Pan African product, see St. Clair Drake, "Diaspora Studies and Pan Africanism" in Global Dimensions of the African Diaspora, ed. Joseph Harris (Washington, D.C.: Howard University Press, 1982), 475; for information on Drake's father, see St. Clair Drake, letter to Michael Fitzgerald, 20 February 1986, Box 2, Folder 52, St. Clair Drake Papers; for an obscure biographical reference to John Gibbs St. Clair Drake, see Joseph B. Earnest, The Religious Development of the Negro in Virginia (Dissertation: University of Virginia, 1914), 208.

18. George Clement Bond, Interview with St. Clair Drake, “A Social Portrait of John Gibbs St. Clair Drake, 763; C.L.R. James, Beyond A Boundary (London: Yellow Jersey Press, 2005), 68-69; Biographical notes on St. Clair Drake, n.d., Faculty Biographical Collections, Roosevelt University Archives, Box 3, Folder 1; see also Earnest, The Religious Development of the Negro in Virginia, 208; for a brief history of Harrison College see Courtney Blackman, "Harrison College: The Cradle of Leadership," (lecture: University of the West Indies, 30 April 2008).

19. Drake and Cayton, 58

20. Winston James, Holding Aloft the Banner of Ethiopia: Caribbean Radicalism in Early Twentieth Century America (London and New York: Verso, 1998), 41, 45. 763.

21. Bond, Interview with St. Clair Drake, "A Social Portrait of John Gibbs St. Clair Drake,"

22. Drake and Cayton, Black Metropolis, 7; see also Edward Ayers, Southern Crossing: A History of the American South, 1877-1905 (Oxford and New York: Oxford University Press, 1995), 100.

23. J. Lewis Peyton, A History of Augusta County, Virginia (Staunton: Samuel Yost and Sons, 1935), 257-258; St. Clair Drake, letter to Michael Fitzgerald, 20 February 1986, Box 2, Folder 52; George Clement Bond, Interview with St. Clair Drake, "A Social Portrait of John Gibbs St. Clair Drake," 764.

24. Drake and Cayton, 119; Peyton, 265-268.

25. C. Vann Woodward, The Strange Career of Jim Crow (New York: Oxford University Press, 1957), 70-88; see also Ayers, Southern Crossing, 100; see also Richard B. Sherman, "The Fight for Racial Integrity in Virginia in the 1920s", Journal of Southern History 54, no. 1 (February 1988), $69-70$.

26. Drake and Cayton, Black Metropolis, 381; for a discussion of Black Baptist initiatives in regards to black women, see Evelyn Brooks Higginbotham, Righteous Discontent: The Women's Movement in the Black Baptist Church (Cambridge: Harvard University Press, 1993), 273; see also Anne Firor Scott, "Most Invisible of All: Black Women's Voluntary Associations," Journal of Southern History 56, no. 1 (February 1990), 3-22; Drake mentions activities of his mother as a churchwoman and clubwoman, see Bond, Interview with St. Clair Drake, "A Social Portrait of John Gibbs St. Clair Drake," 764.

27. Earnest, 208.

28. Drake and Cayton, 58.

29. Ibid., 42, 413.

30. St. Clair Drake, "The Black University in the American Social Order," 883.

31. Earnest, 117; for a history of the Virginia Seminary, see also William Dabney Tyree, Virginia Seminary: The Development of Its Educational Philosophy (Thesis: Virginia Theological Seminary and College, 1955).

32. George Shepperson and Thomas Price, Independent African: John Chilembwe and the Origins, Setting, and Significance of the Nyasaland Native Rising of 1915 (Edinburgh: The University Press, 1987), 114; Randall Burkett, Black Redemption: Churchmen Speakfor the Garvey Movement (Philadelphia: Temple University Press, 1978), 100.

33. St. Clair Drake, The Redemption of Africa and Black Religion (Chicago: Third World Press, 1970), 53; for a discussion of black participation in the American missionary movement, see Sylvia Jacobs, "The Historical Role of Afro-Americans in American Missionary Efforts in Africa," in Black Americans and the Missionary Movement in Africa, ed. Sylvia Jacobs (Westport, CT and London: Greenwood Press, 1982), 7, 19.

34. Jane Linden and Ian Linden, "John Chilembwe and the New Jerusalem, Journal of African History 12, no. 4 (1971): 639-640.

35. St. Clair Drake, "The Black University in the American Social Order," 883; see also Bond, Interview with St. Clair Drake, 763.

36. Walter H. Williams, "William Henry Sheppard, Afro-American Missionary in the Congo, 1890-1910," in Black Americans and the Missionary Movement in Africa, ed. Sylvia M. Jacobs (Westport, CT.: Greenwood Press, 1982), 135-154; for larger biographies of Sheppard, see William H. Sheppard, Presbyterian Pioneers in Congo (Richmond, VA: Richmond Press, 1917) and Pagan Kennedy, Black Livingstone: A True Tale of Adventure in the Nineteenth Century Congo (New York: Viking, Penguin Group, 2002).

37. Benjamin Bowser, Interview with St. Clair Drake, "Studies of the African Diaspora: The Work and Reflections of St. Clair Drake," 4-5; "Dr. Sheppard tells of his ordeal in the Congo," Pittsburgh Courier (May 31, 1923): 7; St. Clair Drake, 1986 interview by unknown, "Conversations 
with St. Clair Drake," video recording, Program of African Studies for African Studies, PVT1311, Melville Herskovits Africana Studies Library, Northwestern University.

38. Bond, Interview with St. Clair Drake, 764; for Drake's discussion of these clergymen, see also St. Clair Drake, letter to Frank Untermyer, ca. 1986, Frank Untermyer Papers, authors possession; see also Drake's notations on the cover of a copy of Burkett's Black Redemption, Box 2, Folder 22, St. Clair Drake Papers.

39. Drake and Cayton, Black Metropolis, 398, 427-28; St. Clair Drake, letter to Randall Burkett, 20 September 1988, Box 5, Folder 28, St. Clair Drake Papers.

40. For a brief discussion of Digg's relationship to the Garvey movement, see Robert A. Hill, Marcus Garvey and Universal Negro Improvement Association Papers, vol. III (Berkley and Los Angeles: University of California Press, 1984), fn5, 695; for a discussion of the CPA, see V.P. Franklin, "The Philadelphia Race Riot," in African Americans in Pennsylvania: Shifting Historical Perspectives, eds., Joe William Trotter and Eric Ledell Smith (University Park: Pennsylvania University Press, 1997), 323; for a discussion of Moses' connection to the Virginia Seminary and Marcus Garvey, see Randall Burkett, Black Redemption, 122-137; for a discussion of Garvey's relationship to the Ku Klux Klan, see E. David Cronon, Black Moses: The Story of Marcus Garvey (Madison: University of Wisconsin Press, 1955, rpt.1969), 187-189; for a discussion of Austin's role in the formation of the NRC, see Fox, The Guardian of Boston: William Monroe Trotter (New York: Antheneum, 1970), 257-259; Drake specifically mentioned his father's involvement in this initiative led by Austin, though there is no supporting evidence, see Bond, Interview with St. Clair Drake, 764; for a discussion on the history of federal surveillance of the Garvey movement, see Theodore Kornweibel, Seeing Red: Federal Campaigns Against Black Militancy, 1919-1925 (Bloomington: Indiana University Press, 1998).

41. Bond, Interview with St. Clair Drake, 764.

42. Donald Roth, "The Black Man's Burden: The Racial Background of Afro-American Missionaries and Africa," in Black Americans and the Missionary Movement in Africa, 37; St. Clair Drake, lecture, Roosevelt University (ca. 1986), Box 6, Folder 1, St. Clair Drake Papers.

43. St. Clair Drake, The Redemption of Africa and Black Religion, 73-74.

44. Robin D.G. Kelly, "But A Local Phase of A Word Problem: Black History's Global Vision, Journal of American History 86, no. 3 (December 1959), 1057-58.

45. Bond, Interview with St. Clair Drake, 764.

46. Drake and Cayton, 413.

47. Ibid., 58 .

48. Joe W. Trotter and Jared N. Day, Race and Renaissance: African Americans in Pittsburgh Since WWII (Pittsburgh: University of Pittsburgh Press, 2010), 9; the place of black people in industrial history of the Tidewater made the choice of Pittsburgh almost a natural one, see Charles Dew, Ironmaker to the Confederacy: Joseph R. Anderson and the Tredeger Iron Works (New Haven: Yale University Press, 1966).

49. Trotter and Day, 9-11.

50. St. Clair Drake, letter to Frank Untermyer, ca. 1986.

51. Drake and Cayton, 112-113; Trotter and Day, 14.

52. St. Clair Drake, letter to Michael Fitzgerald, 20 February 1986, Box 2, Folder 52, St. Clair Drake Papers; Drake and Cayton, 101.

53. Drake and Cayton, 388.

54. For a discussion of black churches in Pittsburgh, see Trotter and Day, 15-16; St. Clair Drake, letter to Frank Untermyer, ca. 1986; Biographical Collections, Roosevelt College Archives, Box 3, Folder 1; Drake's interest in the Black Church is evident in Black Metropolis as well as in a memoranda prepared for Gunnar Myrdal's American Dilemma, see St. Clair Drake, The Negro Church and Associations in Chicago (1 June 1941), unpublished, author's possession.

55. Trotter and Day, 20; Drake and Cayton, 433-34, 56.

56. Trotter and Day, 12; Drake and Cayton, 433.

57. St. Clair Drake, folder marked "autobiographical sketch," ca. 1966, Frank Untermyer Papers, author's possession.

58. Trotter and Day, 21; Drake and Cayton, 386-87.

59. Drake and Cayton, 218; Trotter and Day, 12-13.

60. Trotter and Day, 13.

61. St. Clair Drake, letter to Michael Fitzgerald, 20 February 1986; see also Bowser, Interview with St. Clair Drake, "Studies of the African Diaspora," 4; Biographical Sketch of St. Clair Drake, Associate Professor of Sociology, Roosevelt College, Roosevelt University Archives; Trotter and Day, 15.

62. Trotter and Day, 23.

63. St. Clair Drake, letter to Frank Untermyer, ca. 1986; see also Bond, Interview with St. Clair Drake, "A Social Portrait of John Gibbs St. Clair,” 763.

64. Randall Burkett, letter to author, 22 June 2003, author's possession; see also unknown, "Local Pastor Departs for the West Indies," Pittsburgh Courier (October 11, 1923): 13. 
65. St. Clair Drake, folder marked “autobiographical sketch,” ca. 1966, Frank Untermyer Papers, author's possession; Bowser, 21; Bond, 775.

66. Winston James, 45-46; Biographical Sketch of St. Clair Drake, Associate Professor of Sociology, Roosevelt College.

67. "Staunton News," Pittsburgh Courier (May 10, 1924), 7; St. Clair Drake, letter to Michael Fitzgerald, 20 February 1986.

68. For specific reference to Drake's father in UNIA circles, see Randall Burkett, Garveyism as a Religious Movement: The Institutionalization of Black Civil Religion (Metuchen, NJ and London: Scarecrow Press, Inc. and The American Theological Library Association, 1978), 132; after leaving Bethany Baptist Church, Drake's father resurfaced in 1926 as International Organizer for the UNIA, see Robert A. Hill, ed., The Marcus Garvey and UNIA Papers, volume 6, September 1924-December 1927 (UCLA Press: Berkley, 1989), 117, 440; the activities of Drake's father as International Organizer were covered extensively in the Negro World, see, unknown, "Fine Tributes to Marcus Garvey as Anniversary of the First World Convention is Observed," Negro World (August 7 , 1926), 2; also see unknown, "President General's Inspiring Message Kindles Enthusiasm at Monster Convention Meeting," Negro World (August 8, 1926), 3; in 1927, Drake's father undertook a new position within the UNIA as Headmaster of Liberty University, located near Jamestown, Virginia, see Hill, Marcus Garvey Papers, vol.6, 440; the fundraising efforts of Drake's father on behalf of Liberty University received extensive coverage in the Negro World, see, unknown, "Dr. J.G. St. Clair Drake Gives Details of Property Purchase," Negro World (July 24, 1926), 3; unknown, "The UNIA Buys Quarter Million Dollar Property for Great Negro University," Negro World (July 7, 1924), front page; also see unknown, "Negroes Should Unite and Make University Project a Striking Success," Negro World (August 7, 1926), 3; St. Clair Drake, letter to Frank Untermyer, ca. 1986.

69. St. Clair Drake, folder marked "autobiographical sketch," ca. 1966, Frank Untermyer Papers, author's possession; Bowser, Interview with St. Clair Drake, "Studies of the African Diaspora," 5, 7; Bond, Interview with St. Clair Drake, “A Social Portrait of John Gibbs St. Clair Drake,” 764.

70. Bowser, Interview with St. Clair Drake, "Studies of the African Diaspora," 5; Bond, Interview with St. Clair Drake, "A Social Portrait of John Gibbs St. Clair Drake," 764. Thomas Young, "Principal of Booker T. Pledges to Endeavor to Keep the Standard High," Norfolk Journal and Guide (July 1, 1927), front page; see also unknown, "Winston Douglass at Booker T. Washington High," Journal Norfolk Journal and Guide (June 25, 1927), front page; Unknown, "Academic Program at Booker T. Washington High School," Norfolk Journal and Guide (February 2, 1927), 4.

71. Raymond Wolters, The New Negro on Campus (Princeton: Princeton University Press, 1975), 232.

72. Enoch Waters, American Diary: A Personal History of the Black Press (Chicago: Path Press, 1983), 62; James D. Anderson, The Education of Blacks in the South, 1860-1935 (Chapel Hill and London: University of North Carolina Press, 1988), 273.

73. David Levering Lewis, W.E.B. Du Bois: A Biography of a Race, 1868-1919 (New York: Henry Holt, 1993), 202; Waters, American Diary, 62; St. Clair Drake, "Mbiyu Koinange and the Pan African Movement," in Pan African Biography, ed. Robert Hill (Los Angeles: African Studies Center University of California, Los Angeles, 1987), 167.

74. Waters, American Diary, 62.

75. F. Abiola Irele and Bioudun Jeyifo, Oxford Encyclopedia of African Thought (New York: Oxford University Press, 2010) 27-28; St. Clair Drake, "Mbiyu Koinange and the Pan African Movement," 161-170.

76. St. Clair Drake, "Mbiyu Koinange and the Pan African Movement," 161-170.

77. Bond, Interview with St. Clair Drake, "A Social Portrait of John Gibbs St. Clair Drake," 766; St. Clair Drake, "Reflections on Anthropology and the Black Experience," 90-91.

78. Wolters, The New Negro on Campus, 248; Bond, Interview St. Clair Drake, "A Social Portrait of John Gibbs St. Clair Drake," 766.

79. Unknown, "Hampton Bars Public From Its Stadium," Hampton Daily News 15 (December 3, 1926), front page; Wolters, New Negro on Campus, 236.

80. Bowser, Interview St. Clair Drake, "Studies of the African Diaspora," 5.

81. Even though Drake maintains that the strike not raise "any sharp questions about segregation, it did constitute a black response to the widening of segregation in Virginia as evidenced by Gregg's policies, Bond, Interview St. Clair Drake, "A Social Portrait of John Gibbs St. Clair Drake," 765-766.

82. W.E.B. Du Bois, "The Hampton Strike," draft of essay submitted to The Nation, 20 November 1927, W.E.B Du Bois Papers, 4877/ 82-212; see also W.E.B. Du Bois, "Hampton Students Strike for Justice, Du Bois Papers, 4877/ 22-237.

83. Bond, Interview St. Clair Drake, "A Social Portrait of John Gibbs St. Clair Drake,” 766; Wolters, New Negro on Campus, 267.

84. James E. Gregg to Parents and Guardians of the Strike, 14 October 1927, W.E.B. Du Bois Papers, 4877/ 22-235; St. Clair Drake, "Mbiyu Koinange and the Pan African Movement," 169.

85. James E. Gregg to Parents or Guardians of the Students of Hampton Institute, 14 October 1927, Du Bois papers 4877/ 22-35; Wolters, New Negro on Campus, 256-257. 

1927), 2

86. Baltimore Afro-American (October 22, 1927), 6; Norfolk Journal and Guide (October 22,

87. Mary Brown to James Gregg, 24 October 1927, W.E.B Du Bois Papers 4877/ 89-314.

88. W.E.B. Du Bois, "The Hampton Strike," draft of essay submitted to The Nation, 20 November, 1927, W.E.B. Du Bois Papers, 4877/ 82-212.

89. St. Clair Drake, "In the Mirror of Black Scholarship," 44.

90. Wolters, The New Negro on Campus, 231; Anderson, 274.

91. St. Clair Drake, “A Student's Tribute,” Hampton Script (September 1929), 3.

92. Anne Key Simpson. Follow Me: The Life and Music of R. Nathaniel Dett (Metuchen, NJ: The Scarecrow Press, 1993); Wolters, The New Negro on Campus, 250; St. Clair Drake, "The Singing of Negro Spirituals at Hampton," Hampton Script (November 9, 1929), front page.

93. Bond, Interview St. Clair Drake, "A Social Portrait," 766; Bowser, Interview St. Clair Drake, "Studies of the African Diaspora, 7; Turner's activities also captured the attention of Garvey's followers, see "Dr. Turner to Sail for Europe," Negro World (24 August 1929), 3; Morris MacGreggor, The Emergence of a Black Catholic Community: St. Augustine's in Washington, D.C. (Catholic University Press of America, 1999), 230-31; Bentley Anderson, Black, White, and Catholic: New Orleans Interacialism, 1947-1956 (Vanderbilt University Press, 2005), 12-14.

94. Drake, "In the Mirror of Black Scholarship," 44; Allison Davis, "Our Negro Intellectuals, Crisis 35, no. 8 (August 1928), 268-269.

95. St. Clair Drake, "Remarks by Drake," 27 September 1986, Box 6, Folder 1, St. Clair Drake Papers; St. Clair Drake, "In the Mirror of Black Scholarship: W. Allison Davis and Deep South,” 44. 96. Drake, introduction to Enoch Waters, American Diary, xvi.

97. Bond, Interview St. Clair Drake, "A Social Portrait of John Gibbs St. Clair Drake,” 763; Bowser, Interview St. Clair Drake, "Studies of the African Diaspora," 5-6.

98. St. Clair Drake, "Reflections on Anthropology and the Black Experience," 91; St. Clair Drake, "Students Answers Professor," 337; St. Clair Drake, "Students Answers Professor," Crisis 37, no. 10 (October 1930), 337.

99. See St. Clair Drake, The Redemption of Africa and Black Religion; Africa and the Black Diaspora (Unpublished Manuscript, St. Clair Drake Papers, Schomberg Center for Research in Black Culture, Box 3); Black Folks Here and There: An Essay in History and Anthropology, Vols. I \& 2 (University of California, Los Angeles: Center for Afro-American Studies, 1987, 1990). 
